\title{
DESVENDANDO O CLIMA E O MEIO AMBIENTE
}

Resenha do livro: Clima e Meio Ambiente, autor: José Bueno Conti

CONTI, J. B. Clima e Meio Ambiente. $7^{a}$ edição. São Paulo: Editora Atual, 2011.96 pág. $\quad$ ISBN: 978-85-357-1375-6 (aluno); ISBN: 978-85-357-1376-3 (professor).

Esta obra apresenta temas da climatologia geral bem como questões voltadas ao meio ambiente e à vulnerabilidade social da população mundial e brasileira aos desastres de origem natural ou àqueles oriundos da ação humana sobre os recursos naturais.

O livro é destinado ao público interessado nos estudos da climatologia e do meio ambiente como membros da sociedade civil, alunos e professores do ensino médio e dos cursos de licenciatura em nível superior.

José Bueno Conti é formado em Geografia pela USP, com doutorado em geografia física. É professor de climatologia desta mesma universidade e tem publicado trabalhos científicos, artigos, capítulos e livros sobre assuntos de grande importância para a sociedade, como a desertificação, as características naturais dos trópicos e as mudanças climáticas globais.

Conti discute nesta obra os benefícios e problemas socionaturais relacionados ao clima. Ele apresenta de forma sintetizada os principais temas da climatologia geral, sendo um material introdutório aos estudos do tempo e do clima.

O livro é dividido em 4 partes, cada uma com 2 ou 3 capítulos.

A parte 1 traz os conhecimentos fundamentais da ciência do clima, como a explicação sobre a camada gasosa da Terra; as variações globais e sazonais do clima; a previsão do tempo; e as condições específicas do clima tropical do globo, com destaque para o Brasil, já que o país se encontra quase que totalmente inserido nesta zona climática. É interessante ressaltar que grande parte dos livros de climatologia a que se tem fácil acesso no Brasil foi produzida nos países da zona temperada e por isso priorizam as condições naturais de seus lugares, restringindo o conteúdo sobre as condições atmosféricas e ambientais das zonas tropicais do globo. Dessa forma, Conti oferece uma visão bem distinta da maioria dos livros acessíveis a estudantes e professores.

A parte 2 discute a importância e influência do clima sobre o ser humano, desde questões que tratam da influência climática nos indivíduos, passando pelo assunto da utilização do clima enquanto recurso energético, através da energia solar e eólica, por exemplo. Mostra também situações em que os humanos influenciam o clima. As catástrofes naturais que resultam da combinação da dinâmica natural do planeta com a utilização da natureza pelos humanos também são abordadas neste tópico. 
A parte 3 aborda fenômenos climáticos e/ou antrópicos que geram condições específicas no clima, como a cidade e o clima urbano, da mesma forma em que são condicionadas a ele, como a atividade agrícola que encontra limites naturais para cada tipo de cultura. Esta parte termina com uma abordagem focada no Brasil, principalmente nos eventos meteorológicos que afetam o meio rural, como as secas, as geadas e as precipitações de granizo e neve, esta última restrita à região Sul do país.

A parte 4 traz os assuntos mais polêmicos relacionados ao clima e à degradação ambiental na atualidade, como o processo de desertificação no mundo e no Brasil a as mudanças climáticas globais. Sobre as mudanças climáticas, o autor aponta questões intrigantes, como as dúvidas que existem a respeito do futuro do clima, principalmente se haverá aquecimento ou resfriamento global. O aquecimento global, o efeito estufa e as variações astronômicas que afetam o clima da Terra também são discutidos nesta quarta parte do livro.

Ao término dos capítulos, o livro apresenta um pequeno glossário, contendo alguns dos principais conceitos da climatologia, uma bibliografia comentada, na qual o autor descreve resumidamente cada obra consultada, uma bibliografia consultada e sites de instituições nacionais e internacionais das áreas ambiental, climatológica e de indicadores sociais.

Diante das características da obra, dos temas abordados e de sua fácil leitura, fica evidente que ela pode ser utilizada tanto para o público acadêmico, quanto para pessoas da sociedade preocupadas com as questões ambientais e climáticas atuais. Como cita o próprio autor na apresentação da obra:

"a compreensão de fenômenos como secas, enchentes e elevação da temperatura não deve ser preocupação exclusiva de cientistas e pesquisadores, mas de todos os cidadãos. É necessário que os indivíduos percebam em que medida tais ocorrências são frutos de fatores naturais ou da ação do próprio ser humano. Após conhecer as várias dimensões dos fenômenos climáticos, cada cidadão será capaz de exigir, tanto das autoridades governamentais como de toda a sociedade, uma ação eficaz voltada para a preservação do meio ambiente e, consequentemente, da vida."

Clima e Meio ambiente é, portanto, um livro atraente que instiga a leitura sobre os temas acima supracitados, sendo uma obra ao mesmo tempo modesta e fascinante. 